\title{
Perspective Technologies of the Treatment of the Wastewaters with High Content of Organic Pollutants and Ammoniacal Nitrogen
}

\author{
Myroslav Malovanyy ${ }^{1 *}$, Oleksandr Moroz', Svitlana Hnatush², Olga Maslovska², \\ Volodymyr Zhuk ${ }^{3}$, Ihor Petrushka ${ }^{1}$, Volodymyr Nykyforov ${ }^{4}$, Andriy Sereda ${ }^{1}$
}

1 Viacheslav Chornovil Institute of Sustainable Development, Lviv Polytechnic National University, S. Bandera Str. 12, Lviv, 79013, Ukraine

2 Faculty of Biology, Ivan Franko National University of Lviv, Hrushevsky Str. 4, Lviv, 79005, Ukraine

3 Institute of Building and Environmental Engineering, Lviv Polytechnic National University, S. Bandera Str. 12, Lviv, 79013, Ukraine

4 Faculty of Natural Sciences, Kremenchuk Mykhailo Ostrohradskiy National University, Pershotravneva Str. 20, Kremenchuk, 39600, Ukraine

* Corresponding author's e-mail: mmal@lp.edu.ua

\begin{abstract}
The paper analyzes the advanced technologies of wastewater treatment with a high content of organic pollutants and ammonium ions. Two different bi-stage scenarios for the treatment of such effluents are proposed. The first scenario includes the pretreatment in aerated lagoons and the final stage at the wastewater treatment plants after appropriate dilution with municipal sewages. The second scenario also includes the first stage in aerated lagoons with a tertiary treatment at the plant for cyanobacteria cultivation with the use of obtained biomass for biofuels production. The effects of the aeration periodicity on the leachate treatment efficiency and also on the composition of microbiocenosis in the aerated lagoons were investigated. The leachates of the Lviv landfill of municipal solid waste (MSW) were used in experimental investigations. The Lviv landfill of MSW was used for domestic and industrial wastes deposition for almost six decades, since the 1960s. It was found that the highest effect of ammoniacal nitrogen removal was obtained in the mode of periodic aeration, with the cycle duration of two hours including the one-hour aeration. It was found that the microorganisms extracted from the leachates of the Lviv MSW landfill are prospective for the new biotechnologies of treatment of the highly concentrated wastewaters, since this microbiocenosis is resistant to the widespread pollutants, in particular to heavy metal ions.
\end{abstract}

Keywords: leachate treatment, aerated lagoon, microbiocenosis, biofuels, wastewater treatment plant.

\section{INTRODUCTION}

The pollution of the hydrosphere as a result of the anthropogenic activity by mine waters (Pavlichenko et al., 2013, Kulikova et al., 2016), industrial wastewaters (Ahmad et al., 2012, Gomelya et al., 2014), municipal sewages (Malovanyy et al., 2016a , Blyashyna et al., 2018) and landfill leachates (Govahi et al., 2012, Malovanyy et al., 2018) constitutes a significant environmental threat. Biological treatment processes in the hydrosphere, which are present in any ecosystem, were analyzed. However, the results of their implementa- tion, do not always lead to achieving the required degree of treatment. Sometimes, the secondary pollution by the obtained additional biomass itself creates significant environmental problems. A striking example of this effect is the process of water treatment in artificial water reservoirs of the river Dnipro basin from organic contaminants and biogenic elements using the cyanobacteria. The secondary effect of this treatment is the uncontrolled accumulation of the cyanobacteria biomass. The products of cyanobacteria biodegradation result in a strong secondary pollution of not only the water bodies, but the atmosphere as well. 
The first attempts to study the mechanisms of hydrobiocenoses self-treatment were made in the early 1900s. Providing, preserving and restoring this ability are important goals of the concept of sustainable development - an advanced strategy of the $21^{\text {st }}$ century. Hence, scientific foundations, intended on the improvement of the organization, structuring, selection and intensification of these biological processes, should be done.

Starting from the time they are used at the wastewater treatment plants (WWTP), the study of the existing consortia and the creation of new strains of microorganisms that provide for the selective treatment of wastewater of different chemical compositions become widespread. The adjustment of biological treatment processes in structures and apparatus of certain types with the purpose of their unification, optimization of energy consumption, immobilization of microbiocenoses on carriers, ensuring the appropriate aeration mode, etc are also important aspects.

It should be noted that the specific feature of biological treatment processes involves the limited possibilities to optimize the treatment parameters. Since such processes are usually implemented in large-scale structures or in georeactors simulating natural conditions, it is virtually impossible to regulate the temperature of the whole medium; it is possible to take into account only the influence of the temperature on technological parameters of the process. At the municipal wastewater treatment plants, there is often no technical ability to regulate both the flow rate of wastewater in the entering sewages and the concentration of contaminants (it is usually assumed that the changes in these parameters are cyclic in time, and the corresponding average values vary in relatively narrow ranges).

The paper presents an investigation of promising technologies for the treatment of wastewaters with high level of organic pollutants and high concentrations of ammonium nitrogen. Typical examples of such sewages are the liquid phase of the biodegradation products of organic wastes - landfill leachates, as well as the filtrates from the sludge dewatering plants at the wastewater treatment plants.

The especially toxic leachates with extremely high concentrations of organic contaminants and ammonium nitrogen are a significant threat to environmental pollution in the areas around the MSW landfills. Gao et al., 2015, Malovanyy et al., 2016b, presented detailed reviews of the methods for preliminary treatment of leachates, allowing their subsequent complete treatment at the municipal WWTP. The main element of most technologies of leachate pretreatment is the prolonged aeration, which is most often implemented in specially equipped georeactors or aerated lagoons. The total duration of the aeration process of leachate in such structures can continue even for up to two months. The main result of the aerobic pretreatment is a significant reduction in the content of organic contaminants in leachate, which decreases the load on the municipal WWTP and allowing treating the mixtures of domestic and industrial wastewater with a small proportion of pretreated leachate.

New results of experimental aerobic pretreatment of leachates (Moroz et al., 2017) showed the technical efficiency and potential cost-effectiveness of using this method of leachate pretreatment in Ukraine as a whole and, in particular, for solving the problem of remediation of the Lviv landfill of MSW. Particular attention was given to compliance with the limit values for discharges of pollutants into urban sewerage system and into the municipal WWTP for such contaminant indicators as chemical oxygen demand (COD) and ammoniacal nitrogen $\left(\mathrm{NH}_{4}-\mathrm{N}\right)$.

Malovanyy et al., 2018, presented the results of systematic laboratory research on the implementation of aerobic treatment of the leachate of Lviv MSW landfill at the model installations in periodic and continuous modes, and also the influence of the hydraulic retention time (HRT) of the leachate in the reactor and the ambient temperature on the efficiency of the previous biochemical treatment of leachate.

Important technological issues, the results of which are presented in this publication, are the study for optimal aeration modes of leachate, which assumes the periodical aeration in time. This will reduce the specific operating costs of the leachate treatment. At the same time, it is expected to achieve a higher degree of the leachate treatment on such important indicators as COD and the concentration of ammoniacal nitrogen.

One of the stages of landfill remediation is the elimination of the leachate ponds, located directly on the territory of landfills. The leachates, accumulated in these ponds, are a source of acute environmental hazards. They contain ammonium and nitrate compounds, heavy metal ions, phenol, chlorides and phosphates at the concentrations many times above the maximum permissible values. The microorganisms in ponds with leachate are the natural components of the cycle of sub- 
stances and provide the formation of the basic properties of these water bodies; thus, they can be used for effective bioremediation of the contaminated areas. The composition of the microbiocenosis of leachate ponds of the Lviv MSW landfill, enabling the leachate biological pretreatment in an aerated lagoon, was investigated.

The possibility of using microalgae for the treatment of wastewaters and leachates from organic contaminations and ammonium ions using the cyanobacteria biomass for biofuels production was explored. The nutrient medium for cultivating microalgae could be untreated wastewater, containing phosphorus and nitrogen compounds, and flue gases containing significant amounts of carbon dioxide - all the main nutrients needed to cultivate cyanobacteria. Despite a large number of studies on the use of cyanobacteria for biofuel production (John et al., 2011, Malovanyy, M. et al., 2016c), the technologies of blue-green algae processing has not found wide application yet. The main reasons are as follows: 1) lack of data on the effect of the cyanobacteria biomass preprocessing to increase the completeness and intensification of its biodegradation; 2) deficiency of information concerning the optimal modes of biogas production; 3) lack of a rational strategy and technologies of the collection and processing of surplus biomass of cyanobacteria. Thus, complex investigations should be done, which would answer the questions of optimal use of both wastewater and flue gases in the technological process of cyanobacteria growing. This will enable not only an effective ecological safety management of surface water bodies but also to obtain a new source of renewable energy.

\section{MATERIALS AND METHODS}

The leachates of the Lviv landfill of municipal solid waste (MSW) were used in the experimental investigations. The Lviv landfill of MSW was used for domestic and industrial wastes deposition for almost six decades, since the 1960s. The chemical composition of the investigated leachate (Malovanyy et al., 2018) is presented in Table 1. It should be noted that such a composition of leachate, with slight differences depending on local conditions, is typical for most Ukrainian MSW landfills.

Maximum permissible concentrations (MPCs) are in compliance with Ukrainian environmental legislation regarding the discharging of treated wastewater into the surface water objects of drinking type of water use.

The results presented in Table 1 show that almost all of the ingredients in the leachate of the Lviv MSW landfill exceed the corresponding MPC values. The most dangerous in the case of complete leachate treatment at municipal WWTP is the content of ammoniacal nitrogen, $\mathrm{BOD}_{5}$ and COD. Table 1 also indicates the variable composition of the leachate, depending on the sampling time. Obviously, this is due to the non-stationary character of the biological decomposition processes, the change in the degree of dilution of leachate by atmospheric precipitation, the influence of external temperature, the variability of the parameters of filtration flows, etc.

The aerobic pretreatment of the leachate of Lviv MSW landfill was experimentally investigated on a model laboratory installation (Fig. 1). In a laboratory, a flask was filled with $4 \mathrm{dm}^{3}$ of

Table 1. Chemical composition of the leachate of Lviv MSW landfill

\begin{tabular}{|c|l|c|c|c|c|c|c|}
\hline \multirow{2}{*}{ No. Indicator } & \multirow{2}{*}{ Unit } & \multicolumn{3}{|c|}{ Concentrations for the samples taken over different periods, $\mathrm{mg} / \mathrm{dm}^{3}$} \\
\cline { 4 - 8 } & & 29.01 .17 & 28.02 .17 & 13.04 .17 & 24.05 .17 & $\mathrm{MPC}$ \\
\hline 1 & $\mathrm{NH}_{4}-\mathrm{N}$ & $\mathrm{mg} / \mathrm{dm}^{3}$ & 548.1 & 847.5 & 932.7 & 1130.8 & 2 \\
\hline 2 & $\mathrm{BOD}_{5}$ & $\mathrm{mg} / \mathrm{dm}^{3}$ & 3760 & 3348 & 3456 & 1415 & 15 \\
\hline 3 & $\mathrm{COD}$ & $\mathrm{mg} / \mathrm{dm}^{3}$ & 6500 & 9678 & 10010 & 8856 & 80 \\
\hline 4 & Cadmium & $\mathrm{mg} / \mathrm{dm}^{3}$ & 0.005 & 0.041 & 0.038 & 0.047 & 0.001 \\
\hline 5 & Chlorides & $\mathrm{mg} / \mathrm{dm}^{3}$ & 3900 & 4368 & 5213 & 4715 & 350 \\
\hline 6 & Cobalt & $\mathrm{mg} / \mathrm{dm}^{3}$ & 0.028 & 0.140 & 0.184 & 0.227 & 0.1 \\
\hline 7 & Ferrum (total) & $\mathrm{mg} / \mathrm{dm}^{3}$ & 10.7 & 14.3 & 14.3 & 13.1 & 0.3 \\
\hline 8 & Manganese & $\mathrm{mg} / \mathrm{dm}^{3}$ & 0.015 & 0.024 & 0.038 & 0.042 & 0.1 \\
\hline 9 & Nickel & $\mathrm{mg} / \mathrm{dm}^{3}$ & 0.09 & 0.12 & 0.13 & 0.13 & 0.1 \\
\hline 10 & Plumbum & $\mathrm{mg} / \mathrm{dm}^{3}$ & 0.12 & 0.11 & 0.12 & 0.14 & 0.03 \\
\hline 11 & Strontium & $\mathrm{mg} / \mathrm{dm}^{3}$ & 0.022 & 0.034 & 0.036 & 0.048 & 7 \\
\hline 12 & Suspended solids & $\mathrm{mg} / \mathrm{dm}^{3}$ & 3011 & 2587 & 2019 & 2845 & - \\
\hline 13 & Total dissolved solids & $\mathrm{mg} / \mathrm{dm}^{3}$ & 15245 & 14875 & 14322 & 13483 & - \\
\hline
\end{tabular}


raw leachate, sampled from one of the storage ponds at Lviv MSW landfill. Aeration was carried out using a laboratory aerator. The volume flow of air, assigned to the normal temperature and pressure, was unchanged in the process of aeration and equal $42 \mathrm{~cm}^{3} / \mathrm{s}$, which corresponds to the aeration volume intensity of $37.8 \mathrm{~m}^{3} /\left(\mathrm{m}^{3} \times \mathrm{hr}\right)$ or the specific aeration intensity per unit area $\mathrm{J}=12.6 \mathrm{~m}^{3} /\left(\mathrm{m}^{2} \times \mathrm{hr}\right)$ when depth of the aerated lagoon is $H_{\text {aer }}=3.0 \mathrm{~m}$.

The study of the effect of the aeration mode on the efficiency of the aerobic pretreatment of the Lviv MSW landfill leachate from the ammonium ions was carried out for three cases:

1. continuous aeration with constant intensity;

2. periodic aeration No. 1: 1 hour of aeration / 1 hour without air supply;

3. periodic aeration No. 2: 1 hour of aeration / 4 hours without air supply.

Aeration timing was provided by connecting the compressor-aerator through the time relay, which was set at the appropriate mode for switching on and switching off the aerator. The studies were performed in the periodical mode, in the batch reactor, without input of the fresh portions of the raw leachate. The aeration of the leachate was carried out at a constant ambient temperature of $20^{\circ} \mathrm{C}$. The initial concentration of ammoniacal nitrogen in raw leachate was $C_{0}=805 \mathrm{mg} / \mathrm{dm}^{3}$ and the initial $\mathrm{pH}$ value $-\mathrm{pH}=8.46$. Periodically, usually once a day, the samples were taken for analysis. The concentration of ammoniacal nitrogen was determined with a photometric method.

In order to study the microbiocenosis of the leachate ponds at the Lviv MSW landfill, a number of samples from the pond No. 5 were taken from the free surface and on depths of $0.5 \mathrm{~m}$ and $1 \mathrm{~m}$. The counting of microorganisms of various groups was carried out with surface sowing of suspensions of diluted leachates on agarized nutritional media using the method of direct calculation of colony-forming units (CFU). The orientation of microbiological processes in leachates was determined by (Andrejuk K.I. et al., Volkogon, V.V. et al., 2010). On the meat-peptone nutrient agar, the number of bacteria that assimilate nitrogen of organic compounds was taken into account; on the starch-ammonia environment - the number of microorganisms that metabolize mineral forms of nitrogen; on the Czapek medium and on the wort agar - micromycetes; on the Ashby's agar - oligonitrophilic microorganisms; on the Menkina medium - bacteria that metabolize phosphate of organic compounds; on agarized leachate - pedotrophs; on the hungry agar - oligotrophs, on the Hiltay medium - the denitrifying microorganisms. Calculation of the CFU in $1 \mathrm{~cm}^{3}$ of leachate was performed taking into account the dilution of samples according to the generally accepted method (Tepper E.Z. et al., 1987).

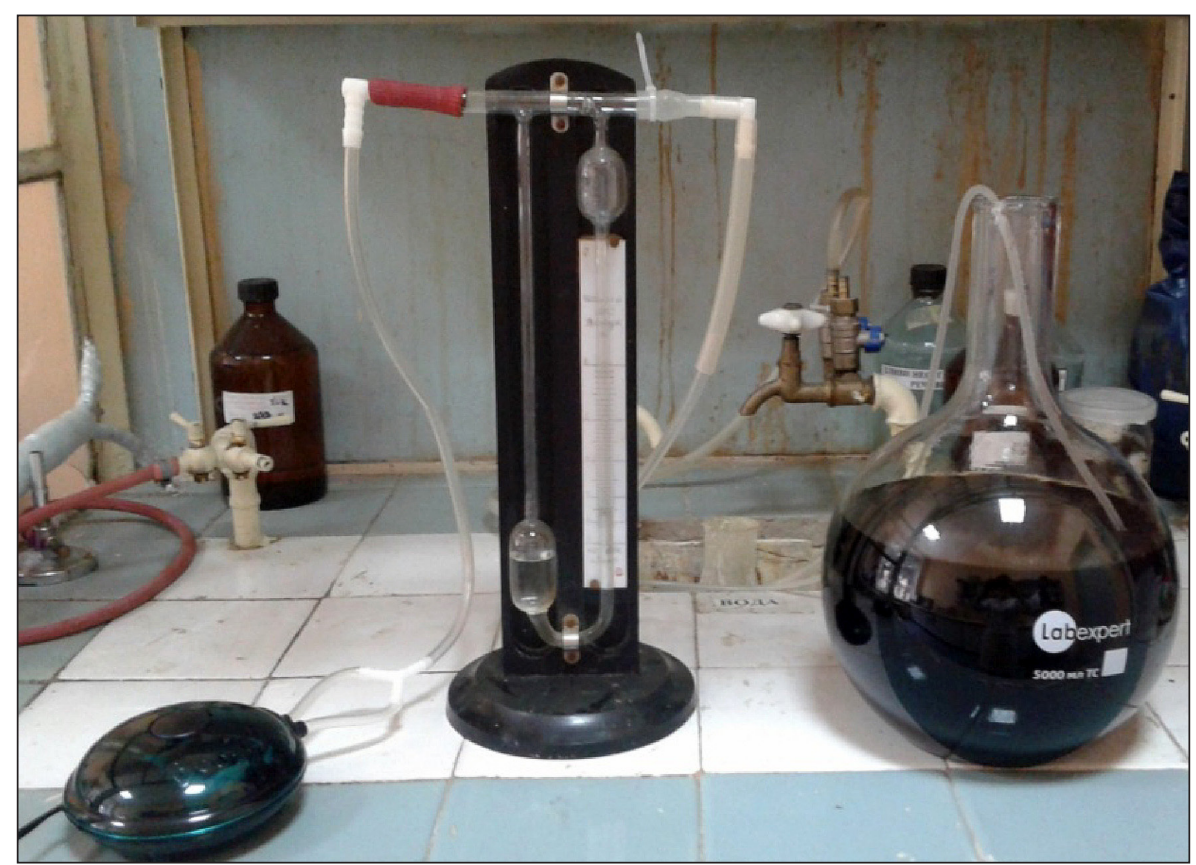

Fig. 1. Experimental lab-scale installation for the study of aerobic leachate pretreatment 


\section{RESULTS AND DISCUSSION}

One-stage biological treatment of highly concentrated wastewater is unlikely to achieve the necessary treatment effect by organic contaminations and ammonium nitrogen. Two scenarios of two-stage treatment of such wastewater were considered in this paper.

The first scenario:

- stage 1 - aerobic biochemical pretreatment in aerated lagoons;

- stage 2 - complete treatment at municipal WWTP after appropriate dilution with sewages.

The second scenario:

- stage 1 - aerobic biochemical pretreatment in aerated lagoons;

- stage 2 - tertiary treatment at the plant for cyanobacteria cultivation with the utilization of excess biomass for the biofuels production.

The first scenario was presented in detail in (Moroz et al., 2017, Malovanyy, M. et al., 2018). The studies of the first stage, which is the same in both scenarios, found that in the biological aerobic treatment of the leachate of Lviv MSW landfill in the continuous mode, the optimal hydraulic retention time in the reactor is about 10 days. The change in the relative concentration of the ammonium nitrogen in the leachate largely depends on the temperature of the process. Therefore, for the implementation of this type of two-stage treat- ment technology for landfill leachates using the aeration lagoons and municipal WWTP, it is necessary to adjust the modes of implementation of individual processes, depending on the temperature of the environment.

In order to optimize the energy consumption of aerobic pretreatment, experimental studies of the effect of periodic aeration on the treatment efficiency were performed. The study was carried out according to the method described above. The criterion for leachate treatment from ammonium ions is the ratio of the current concentration of ammonium nitrogen $C(t)$ to its initial value $C_{0}$.

The main result of this study is that the treatment effect by ammoniacal nitrogen in the No. 1 mode of periodic aeration is even higher than in the case of continuous aeration (Fig. 2). However, in the No. 2 mode of periodic aeration (1 hour of aeration and 4 hours of break), the treatment effect by ammoniacal nitrogen is the lowest among the three investigated modes at all time intervals.

The obtained experimental results are described by the exponential functions

$$
C / C_{0}=\exp (-k t)
$$

which is a general analytical solution for the first-order chemical reactions.

The approximation of the experimental results obtained by the method of least squares allows obtaining for the continuous aeration mode dependence

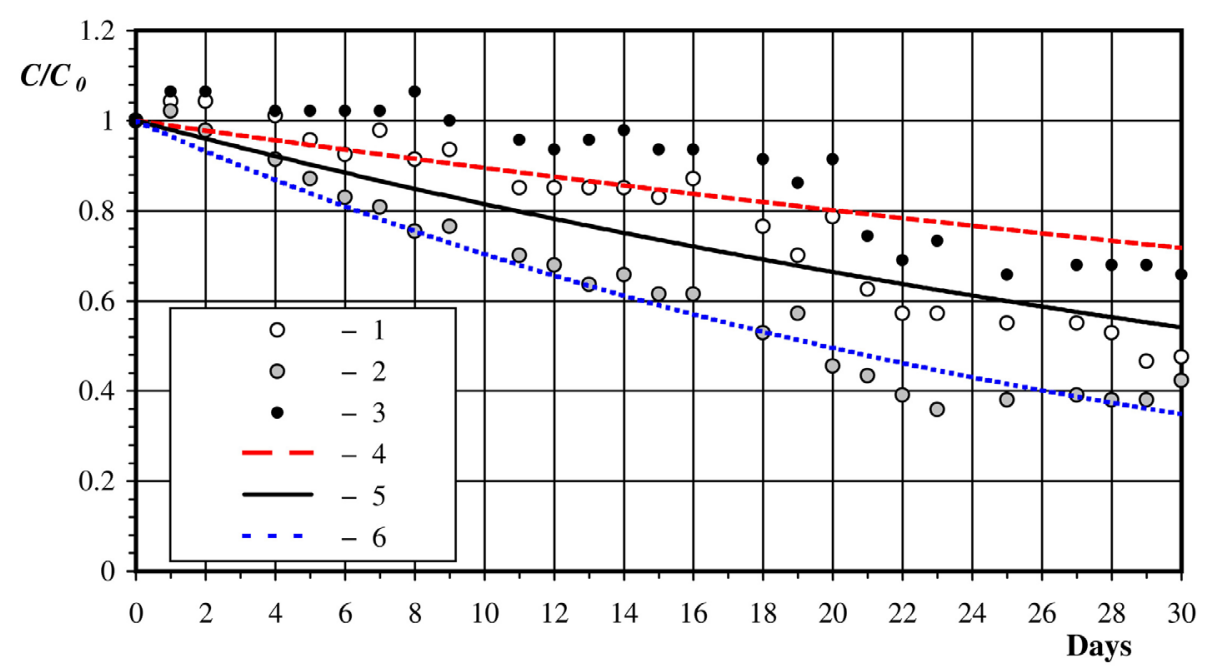

Fig. 2. Change of the relative concentration of ammonium nitrogen in leachate at different aeration modes $\left(C_{0}=805 \mathrm{mg} / \mathrm{dm}^{3} ; \mathrm{pH}_{0}=8.46 ; T=20^{\circ} \mathrm{C}\right)$ :

1 - continuous aeration; 2 - periodic aeration No. 1 (1 hour aeration / 1 hour break);

3 - periodic aeration No. 2 (1 hour aeration / 4 hours break);

4, 5, 6- are the exponential approximations, respectively (4), (2) and (3) 


$$
C / C_{0}=\exp (-0,0205 t)
$$

where: $t$ - time from the beginning of aeration, days.

The coefficient of determination $\mathrm{R}^{2}=0.841$ of exponential dependence (2) for the continuous aeration mode indicates the average approximation level of the dependence (2) comparing the experimental results.

For the periodic aeration mode No. 1 the value of the exponent coefficient $k$ is 1.71 times more compared with continuous aeration:

$$
C / C_{0}=\exp (-0,0351 t)
$$

and significantly higher coefficient of determination $\mathrm{R}^{2}=0.941$.

At the same time, the decrease in the relative time of the leachate aeration to the total time of to the ratio $t^{\prime}=0.2$ (for the periodic aeration system No. 2) caused a decrease of the exponential coefficient by almost a half, comparing with the continuous aeration mode:

$$
C / C_{0}=\exp (-0,0111 t)
$$

The approximation dependence (4) has the lowest value of the coefficient of determination $\mathrm{R}^{2}=0.691$ among three investigated modes.

In general, only for the periodic aeration mode No. 1 , the coefficient of determination is quite high $\left(\mathrm{R}^{2}=0.941\right)$ indicating a strong functional dependence.

At the same time, it should be noted that there are no changes of the ammoniacal nitrogen concentrations at the beginning of the aeration process. For a continuous aeration mode, the content of ammonium ions, with error accuracy, was virtually unchanged during the first 4 days of aeration, whereas in periodic aeration mode No. 1, this term was equal 2 days, and in the periodic aeration mode No. 2, it was delayed to 9 days.

This effect may indicate the predominance of the biochemical treatment processes of leachate comparing with the chemical oxidation of ammonium ions, and the time of initial delay should be considered as the period for the formation of corresponding aerobic microbiocenosis in the leachate.

As a result of the microbiocenosis research of the leachate ponds at Lviv MSW landfill, the largest number of CFU was detected in the sample taken from the free surface. The dominant ecotrophic group in all selected samples was pedo- trophic microorganisms, which is probably due to their trophic specificity and resistance to the toxic compounds in leachate. At the depth of $1.0 \mathrm{~m}$, the number of pedotrophic microorganisms was the highest. The most numerous ecological trophic groups in the pond No. 5 were oligotrophic microorganisms, nitrifying, phosphate-mobilizing bacteria and microorganisms that metabolize nitrogen of inorganic compounds. The number of micromycetes and microorganisms that assimilate the organic nitrogen was lower. Denitrifying bacteria were detected in the sample which was taken from the water surface. In the samples taken from the depths of $0.5 \mathrm{~m}$ and $1.0 \mathrm{~m}$, no denitrifying bacteria were detected. The number of CFU of all investigated ecological trophic groups, except for the pedotrophic microorganisms, decreased with increasing the depth of sampling, which is probably due to the aeration mode.

The predominance of certain groups in the biotope is a reflection of the physical and chemical processes in it. The domination of pedotrophic microorganisms in all investigated samples of leachate probably indicates a significant technogenic loading on the reservoir, which resulted in the formation of a unique group of microorganisms that is capable of degrading toxic organic substances, including phenol, and is simultaneously resistant to their effects and the effects of heavy metals ions, as well as compounds of nitrogen and chlorides.

The leachate from the pond No. 5 was aerobically treated at the experimental installation (Fig. 1). After the aeration of leachate in the sludge, covering the bottom and walls of the lagoon, the number of microorganisms that assimilate nitrogen of organic compounds, microorganisms that assimilate nitrogen of inorganic compounds, oligotrophic, nitrifying and pedotrophic microorganisms was higher compared to the leachate in lagoon. We assume that in the process of aerobic treatment of leachate, the microorganisms form a biofilm, so the number of these groups in the sludge is higher than in the leachate. Denitrifying bacteria were detected in the sludge, whereas in the raw leachate they are absent, which may also indicate the formation of biofilm with the bacteria of sludge.

It was established that the microorganisms extracted from the Lviv MSW landfill leachate are promising for the biotechnologies of highly contaminated wastewaters treatment, since they are resistant to the vast majority of pollutants, in 
Table 2. Ecological and trophic groups of microorganisms in the Lviv MSW landfill leachate

\begin{tabular}{|c|c|c|c|c|c|c|c|c|c|c|}
\hline \multirow[b]{2}{*}{ Sample } & \multicolumn{10}{|c|}{ Number of microorganisms (CFU / $1 \mathrm{~cm}^{3}$ leachate) } \\
\hline & $\begin{array}{l}\text { Microorganisms } \\
\text { that assimilate } \\
\text { nitrogen } \\
\text { of organic } \\
\text { compounds }\end{array}$ & $\begin{array}{l}\text { Oligotrophic } \\
\text { microorgan- } \\
\text { isms }\end{array}$ & $\begin{array}{l}\text { Microorganisms } \\
\text { metabolize } \\
\text { nitrogen of } \\
\text { inorganic } \\
\text { compounds }\end{array}$ & $\begin{array}{l}\text { Oligonitrophilic } \\
\text { microorganisms }\end{array}$ & Micromycetes & $\begin{array}{l}\text { Nitrifying } \\
\text { bacteria }\end{array}$ & $\begin{array}{c}\text { Denitrifying } \\
\text { bacteria }\end{array}$ & $\begin{array}{l}\text { Microorganisms } \\
\text { that metabolize } \\
\text { phosphate } \\
\text { of organic } \\
\text { compounds }\end{array}$ & $\begin{array}{c}\text { Pedotrophic } \\
\text { microorganisms }\end{array}$ & $\begin{array}{l}\text { The total } \\
\text { number } \\
\text { of CFU }\end{array}$ \\
\hline $\begin{array}{l}\text { Surface of the } \\
\text { leachate pond }\end{array}$ & $7 \cdot 10^{5}$ & $4 \cdot 10^{6}$ & $1 \cdot 10^{6}$ & $2 \cdot 10^{6}$ & $7 \cdot 10^{4}$ & $2 \cdot 10^{6}$ & + & $2 \cdot 10^{6}$ & $7 \cdot 10^{6}$ & $4 \cdot 10^{7}$ \\
\hline Depth $0.5 \mathrm{~m}$ & $2 \cdot 10^{4}$ & $4 \cdot 10^{4}$ & $1 \cdot 10^{4}$ & $2 \cdot 10^{4}$ & $1 \cdot 10^{5}$ & $1 \cdot 10^{6}$ & - & $1 \cdot 10^{4}$ & $1 \cdot 10^{6}$ & $8 \cdot 10^{6}$ \\
\hline Depth $1.0 \mathrm{~m}$ & $2 \cdot 10^{3}$ & $2 \cdot 10^{2}$ & $1 \cdot 10^{5}$ & $9 \cdot 10^{4}$ & $1 \cdot 10^{4}$ & $1 \cdot 10^{5}$ & - & $7 \cdot 10^{3}$ & $9 \cdot 10^{6}$ & $2 \cdot 10^{7}$ \\
\hline $\begin{array}{l}\text { Leachate in } \\
\text { aerated lagoon }\end{array}$ & $2 \cdot 10^{4}$ & $1 \cdot 10^{2}$ & $1 \cdot 10^{4}$ & $1 \cdot 10^{5}$ & $6 \cdot 10^{2}$ & $6 \cdot 10^{4}$ & - & $4 \cdot 10^{4}$ & $2 \cdot 10^{4}$ & $1 \cdot 10^{7}$ \\
\hline Sludge & $4 \cdot 10^{4}$ & $3 \cdot 10^{4}$ & $2 \cdot 10^{5}$ & $1 \cdot 10^{5}$ & $2 \cdot 10^{5}$ & $6 \cdot 10^{4}$ & + & $6 \cdot 10^{5}$ & $4 \cdot 10^{6}$ & $1 \cdot 10^{7}$ \\
\hline
\end{tabular}

Notes: 1) "+" growth of denitrifying bacteria; "-" no growth of denitrifying bacteria;

2 ) error between the two alternate aggregates did not exceed $15 \%$.

particular heavy metal ions. Among the microorganisms, the strains resistant to the influence of ferrous, chromium and cadmium ions in the concentrations exceeding the maximum permissible concentrations of $3.5 ; 16$ and 32 times, respectively, were detected in the leachate. Among the microorganisms that assimilate the organic nitrogen, 5 strains polyresistant to heavy metal ions were detected. Among the microorganisms that metabolize the nitrogen of inorganic compounds, 13 strains polyresistant to heavy metal ions were detected. The colonies of the investigated polyresistant strains changed their morphology and colour, depending on the metal in the growing medium, which is probably one of the adaptive reactions of these bacteria. The strains resistant to the action of the heavy metal ions are also found among oligotrophs and oligonitrophils.

The second stage of scenario No.1 was studied in detail (Malovanyy M. et al., 2016b, Malovanyy M. et al., 2018). This investigation shows that in the case of leachate treatment at model WWTP in batch mode, at dilution of leachate by the municipal sewage 1:1000, the maximum value of the treatment effect for both ammonium ions and for COD was obtained. In order to treat the leachate at model WWTP in continuous mode stability in time of the treatment effect was proved. The value of the sludge index until the end of the pilot research did not exceed the limiting values for the municipal WWTP operation.

The cultivation of cyanobacteria for using in the treatment technology of highly concentrated organic and ammonia contaminants was investigated by a number of research teams (Troschl et al., 2017, Markou et al., 2014). The authors also investigated the process of complex processing of cyanobacteria by extracting lipids suitable for the production of biodiesel and biogas
(Malovanyy M. et al., 2016c, Nykyforov V. et al., 2016d). The prospect of hydrodynamic cavitation application for increasing the efficiency of lipid extraction and biogas synthesis was shown. The complex strategy of using the cyanobacteria in energy and agricultural technologies was proposed.

\section{CONCLUSIONS}

1. Two variants of the treatment strategy of wastewater with especially high concentrations of organic contaminants and ammoniacal nitrogen were proposed. Each variant involves twostage treatment process, using at the first stage of biological treatment in aerated lagoons. The complete treatment can be realized either at the municipal WWTP, or at the plant for cyanobacteria biomass cultivation, which can then be used for the biofuels synthesis.

2. The experimental laboratory studies pertaining to the influence of the aeration mode on the process of aerobic biochemical pretreatment of the Lviv MSW landfill leachate were performed, using the ammonium nitrogen concentration as indicator of the treatment efficiency. Three aeration modes were investigated: 1) continuous aeration; 2) periodic aeration No.1 with the ratio of the aeration time to the total treatment time $t^{\prime}=0.5 ; 3$ ) periodic aeration No. 2 with the ratio $t=0.2$.

3. As a result of the study, it was found that the time dependence of ammonium nitrogen concentration can be sufficiently well approximated by exponential functions (2) - (4). The highest effect of ammoniacal nitrogen removal was obtained in the No. 1 mode of periodic aeration with the cycle time of two hours and aeration time only of one hour. The practical 
absence of changes in the concentration of ammoniacal nitrogen at the initial periods of the aeration process was explained by the predominance of biochemical treatment of leachate over the chemical oxidation of ammonium ions and formation of the corresponding aerobic microbiocenosis in the leachate during this initial period.

4. It was established that the main groups of microorganisms in leachate of the pond No.5 of Lviv MSW landfill are pedotrophic, oligotrophic and oligonitrophilic microorganisms, as well as microorganisms metabolizing phosphate of organic compounds and nitrogen of inorganic compounds. Probably, these groups of microorganisms are involved in the functioning of microbiocenosis of leachate.

5. The investigation of the properties of strains of microorganisms isolated from technogenic contaminated territories is important for understanding the regulation of bacterial metabolism under stress conditions, including the influence of heavy metals ions, mechanisms of formation of resistance of the microorganism to the influence of the stress factor, and the creation of effective technologies for the biological treatment of wastewaters.

\section{REFERENCES}

1. Ahmad M. et al. 2012. Eggshell and coral wastes as low cost sorbents for the removal of $\mathrm{Pb} 2+$, $\mathrm{Cd} 2+$ and $\mathrm{Cu} 2+$ from aqueous solutions. Journal of Industrial and Engineering Chemistry, 18 (1), 198-204.

2. Andrejuk K.I et al. 2001 Functioning of microbial soils in the conditions of anthropogenic loading. Oberegy, Kiev.

3. Blyashyna M., ZhukovaV., Sabliy L. 2018. Processes of biological wastewater treatment for nitrogen, phosphorus removal by immobilized microorganisms. Eastern-European Journal of Enterprise Technologies, 2(10), 30-37.

4. Gao J., Oloibiri V., Chys M., Van Hulle S. 2015. The present status of landfill leachate treatment and its development trend from a technological point of view. Reviews in Environmental Science and Bio/Technology, 14(1), 93-122.

5. Gomelya M., Trus I., Shabliy T. 2014. Application of aluminium coagulants for the removal of sulphate from mine water. Chemistry and Chemical Technology, 8(2), 197-203.

6. Govahi S., Karimi-Jashni A., Derakhshan M. 2012.
Treatability of landfill leachate by combined upflow anaerobic sludge blanket reactor and aerated lagoon. International Journal of Environmental Science and Technology, 9, 145-151.

7. John R.P., Anisha G., Nampoothiri K.M., Pandey A. 2011. Micro and macroalgal biomass: a renewable source for bioethanol. Bioresour Technol., 102, 186-193.

8. Kulikova D.V., Pavlychenko A.V. 2016. Estimation of ecological state of surface water bodies in coal mining region as based on the complex of hydrochemical indicators. Scientific Bulletin of National Mining University, 4, 62-70.

9. Malovanyy M., Shandrovych V., Malovanyy A., Polyuzhyn I. 2016a. Comparative Analysis of the Effectiveness of Regulation of Aeration Depending on the Quantitative Characteristics of Treated Sewage Water. Journal of Chemistry, 2016, 9 p.

10. Malovanyy M. et al. 2016b. Technological aspects of the pre-treatment of leachate, stored at the retention ponds of the Grybovychi landfill, Lviv region, Ukraine. Water Security, Bristol.

11. Malovanyy M. et al. 2016c. Production of renewable energy resources via complex treatment of cyanobacteria biomass. Chemistry and Chemical Technology, 10(2), 251-254.

12. Malovanyy M., Zhuk V., Sliusar V., Sereda A. 2018. Two stage treatment of solid waste leachates in aerated lagoons and at municipal wastewater treatment plants. Eastern-European Journal of Enterprise Technologies, 1/10 (91), 23-30.

13. Markou G., Vandamme D., Muylaert K. 2014. Microalgal and cyanobacterial cultivation: The supply of nutrients. Water Res., 65, 186-202.

14. Moroz O. et al. 2017. The analysis of the prospects for aerobic treatment of garbage dumps and solid waste landfills infiltrates. Scientific Bulletin of UNFU, 27(3), 83-88. (in Ukraine)

15. Pavlichenko A.V., Kroik A.A. 2013. Geochemical assessment of the role of aeration zone rocks in pollution of ground waters by heavy metals. Scientific Bulletin of National Mining University, 5, 93-99.

16. Tepper E.Z. et al. 1987. Workshop on microbiology, Agropromizdat, Moscow.

17. Troschl C, Meixner R., Drosg B. 2017. Cyanobacterial PHA production - review of recent advances and a summary of three years' working experience running a pilot plant. Bioengineering, 4, 26.

18. Volkogon V.V. et al. 2010. Experimental soil microbiology, Agrarna Nauka, Kyiv.

19. Nykyforov V., Malovanyy M., Kozlovs'ka T., Novokhatko O., Digtiar S., 2016d. The biotechnological ways of blue-green algae complex processing. Eastern-European Journal of Enterprise Technologies, 5/10 (83), 11-18. 